\title{
Knowledge Management sebagai Upaya Pengembangan Learning Organization di Lembaga Pendidikan Islam
}

\author{
Zalik Nuryana \\ Fakultas Agama Islam Universitas Ahmad Dahlan Yogyakarta \\ zalik.nuryana@pai.uad.ac.id
}

\begin{abstract}
Being a superior education institution is the hope of every educational institution, not exception in Islamic education. In the midst of competition between these institutions, Islamic education should be able to respond to changes quickly if it does not want to displaced and dead. Each of Islamic educational institutions that have certain characteristics to be able to be the strength and foundation to become a superior institution. Knowlegde Management as an approach which is based on the understanding that the task of the school is a good understanding of how and when the creation of knowledge should be supported, how to use the accumulated knowledge that has been created so that this knowledge can improve productivity. With the knowledge of their respective Islamic educational institutions and managed properly expected of Islamic educational institutions remained firm stand to become an institution of superior and competitive.
\end{abstract}

Keywords: Knowledge Management, Islamic Education.

\begin{abstract}
Abstrak
Menjadi lembaga pendidikan yang unggul adalah harapan setiap lembaga pendidikan. Tidak terkecuali pendidikan Islam. Di tengah persaingan antar lembaga pendidikan ini, pendidikan Islam harus mampu merespon perubahan dengan cepat apabila tidak ingin tergeser dan mati. Masing-masing lembaga pendidikan Islam yang mempunyai ciri khas tertentu harus mampu menjadi kekuatan dan fondasi untuk menjadi lembaga yang unggul. Knowlegde Management (Manajeman Pengetahuan) sebagai pendekatan yang bertumpu pada pemahaman bahwa tugas sekolah adalah memahami dengan baik bagaimana dan kapan penciptaan pengetahuan harus didukung, bagaimana menggunakan akumulasi pengetahuan yang sudah tercipta sehingga pengetahuan tersebut dapat meningkatkan produktifitas. Dengan bekal pengetahuan yang dimiliki masing-masing lembaga pendidikan Islam dan dikelola dengan baik diharapkan lembaga pendidikan Islam tetap kokoh berdiri menjadi lembaga yang unggul dan berdaya saing.
\end{abstract}

Kata kunci: Knowledge Managemen, Manajemen Pengetahuan, Lembaga Pendidikan Islam.

\section{PENDAHULUAN}

Pendidikan merupakan salah satu sektor penting dalam pembangunan di setiap negara. Menurut Undang-Undang No. 20 Tahun 2003. Untuk mencapai tujuan pendidikan nasional diperlukan pengelolaan pendidikan yang bagus, cerdas, dan mampu bersaing dalam pengembangan pendidikan baik pada sektor pengelolaan maupun hasil pendidikan. Perkembangan masyarakat dunia pada umumnya dan masyarakat Indonesia pada khususnya sudah memasuki masyarakat informasi yang merupakan kelanjutan dari masyarakat modern dengan ciri-cirinya yang 
bersifat rasional, berorientasi ke masa depan, terbuka, menghargai waktu, kreatif, mandiri, dan inovatif. Sedangkan masyarakat informasi ditandai oleh penguasaan terhadap teknologi informasi, mampu bersaing, serba ingin tahu, imajinatif, mampu mengubah tantangan menjadi peluang dan menguasai berbagai metode dalam memecahkan masalah.

Perkembangan zaman ini akan membuat perubahan dalam segala lini kehidupan yang sangat beragam, sehingga yang sanggup bertahan hanyalah mereka yang mempunyai pandangan ke masa depan dan mampu mengubah pengetahuan menjadi kebijakan. Dalam keadaan ini seluruh aspek kehidupan harus berbenah mengikuti tuntutan zaman, tidak terkecuali pendidikan. Inilah kenyataan yang akan terjadi, dan manusia mau tidak mau harus menghadapinya. Masa depan yang demikian itu selanjutnya akan mempengaruhi dunia pendidikan baik dari segi kelembagaan, materi pendidikan, guru, metode, sarana prasarana dan lain sebagainya. Hal ini pada gilirannya menjadi tantangan yang harus dijawab oleh dunia pendidikan. Dalam hal ini pendidikan harus mampu menyiapkan sumber daya manusia yang tidak hanya sekedar sebagai penerima arus informasi global, tetapi juga harus memberikan bekal kepada mereka agar dapat mengolah, menyesuaikan, dan mengembangkan segala hal yang diterima memalui arus informasi itu, yakni manusia yang kreatif dan produktif.

Membangun keunggulan sebuah lembaga pendidikan khususnya lembaga pendidikan Islam di dalam perkembangan zaman dan iklim persaingan yang sedemikian tinggi, mengharuskan lembaga pendidikan Islam menemukan strategi yang lebih sesuai dengan tuntutan perubahan lingkungan persaingan. Strategi seharusnya dibangun atas dasar pemahaman yang menyeluruh mengenai aset atau sumber daya apa yang dapat digunakan pendidikan bila ingin unggul. Lembaga pendidikan Islam yang unggul tidak lagi harus semata-mata bertumbu pada sumber daya finansial, bangunan, tanah, teknologi, posisi, dan lainya. Akan tetapi harus juga bertumpu pada aset pengetahuan.
Knowledge management merupakan satu pendekatan yang bertumpu pada pemahaman bahwa tugas organisasi, dalam hal ini organisasi sekolah, adalah memahami dengan baik bagaimana dan kapan penciptaan pengetahuan harus didukung, bagaimana menggunakan akumulasi pengetahuan yang sudah tercipta sehingga pengetahuan tersebut dapat meningkatkan produktifitas. Objek knowledge management adalah tenaga pendidik dan tenaga kependidikan di lembaga pendidikan Islam. Objek inilah yang akan dikembangkan menjadi sistem kumpulan pengetahuan dari unsur sebuah lembaga pendidikan Islam untuk dapat mengembangkan lembaga pendidikan Islam, sedangkan subjeknya adalah pengelolaan pendidikan Islam dengan menggunakan knowledge management pada lembaga pendidikan tersebut, dengan pemahaman knowledge management ini, lembaga pendidikan Islam akan menjadi lembaga yang unggul dan berdaya saing.

\section{Manajemen Pendidikan Islam}

Terdapat banyak fariasi definisi manajemen yang diajukan oleh para tokoh. Perbedaan ini disebabkan oleh sudut pandang dan latarbelakang keilmuan yang dimiliki para tokoh. Inti dari berbagai sudut pandang dan variasi dari pengertian manajemen menurut Imam Machali, manajemen adalah usaha untuk mengatur organisasi untuk mencapai tujuan yang ditetapkan secara efektif, efisien, dan produktif. Efektif berarti mampu mencapai tujuan dengan baik, sedangkan efisien berarti melakukan sesuatu dengan benar.

Manajemen pendidikan adalah gabungan dari dua kata yang mempunyai satu makna yaitu manajemen dan pendidikan. Manajemen pendidikan adalah seluruh proses kegiatan bersama dalam bidang pendidikan dengan mendayagunakan semua sumberdaya yang ada yang dikelola untuk mencapai tujuan pendidikan. Sumberdaya itu berupa man (manusia=guru, siswa, karyawan), money (uang=biaya), materials (bahan/alat-alat pembelajaran), methods (teknik/cara), machines (mesin=fasilitas), market ( pasar), dan minuts (waktu) yang biasa disebut $7 \mathrm{M}$. 
Mujamil Qomar menjelaskan bahwa manajemen pendidikan Islam adalah suatu proses pengelolaan lembaga pendidikan Islam secara Islami dengan cara menyiasati sumber-sumber belajar dan hal-hal lain yang terkait untuk mencapai tujuan pendidikan Islam secara efektif dan efisien. Sehingga dapat disimpulkan bahwa manajemen pendidikan Islam adalah bentuk kerja sama untuk melaksanakan fungsi-fungsi perencanaan, pengorganisasian, personalia, pengarahan kepemimpinan, dan pengawasan terhadap usaha-usaha para anggota organisasi dan penggunaan sumber daya manusia finansial, fisik dan lainya dengan menjadikan Islam sebagai landasan dan pemandu dalam praktek operasionalnya untuk mencapai tujuan organisasi (pendidikan Islam) dalam menanamkan ajaran atau menumbuhkembangkan nilai-nilai Islam.

\section{Knowledge Management Upaya Pengembangan Learning Organization di Lembaga Pendidikan Islam}

Pergeseran lingkungan dan kekuatan persaingan dalam industri pendidikan menyebabkan timbulnya kesenjangan antara tuntutan lingkungan dan persaingan dengan kekuatan satuan pendidikan pada berbagai jenis dan jenjang pendidikan. Situasi ini memaksa sebagian satuan pendidikan mengurangi atau menghentikan operasinya. Sejumlah program studi pada sejumlah perguruan tinggi mengalami penurunan jumlah mahasiswa, bahkan terpaksa ditutup dan atau dicabut izin operasinya. Ini terjadi pula pada satuan pendidikan dasar, menengah, dan satuan lainnya. Fenomena sejumlah satuan pendidikan emngalami penurunan jumlah siswa/mahasiswanya atau mengurangi/menghentikan operasinya tersebut sangat meluas dan merupakan isu yang penting untuk dikaji.

Arti pentingnya manajemen pengetahuan yang muncul dari rahim kacamata bisnis pada hakikatnya dapat dipahami melalui serangkaian pertanyaan antara lain, mengapa banyak lembaga pendidikan Islam tidak mampu bertahan lama, apa yang menyebabkan sebuah lembaga pendidikan Islam lebih bersaing dibandingkan dengan lembaga pendidikan yang lain. Kemampuan lembaga pendidikan Islam dapat bertahan bukan karena kebetulan akan tetapi lembaga itu pasti mampu menunjukkan kapasitas beradaptasi yang lebih cepat terhadap perubahan kondisi tuntutan lingkungannya, keinginan secara terus menerus untuk melakukan inovasi, dan mengambil keputusan yang tepat untuk menggerakkan lembaga tersebut. Kemampuan tersebut hanya mungkin terwujud apabila lembaga pendidikan Islam dengan efektif mampu menyerap dan menggunakan sumber daya pengetahuan anggotanya, memberi ruang yang kondusif bagi setiap individu dan tim.

Manajemen pengetahuan pada dasarnya muncul untuk menjawab bagaimana seharusnya mengelola pengetahuan. Pada masa lalu muncul

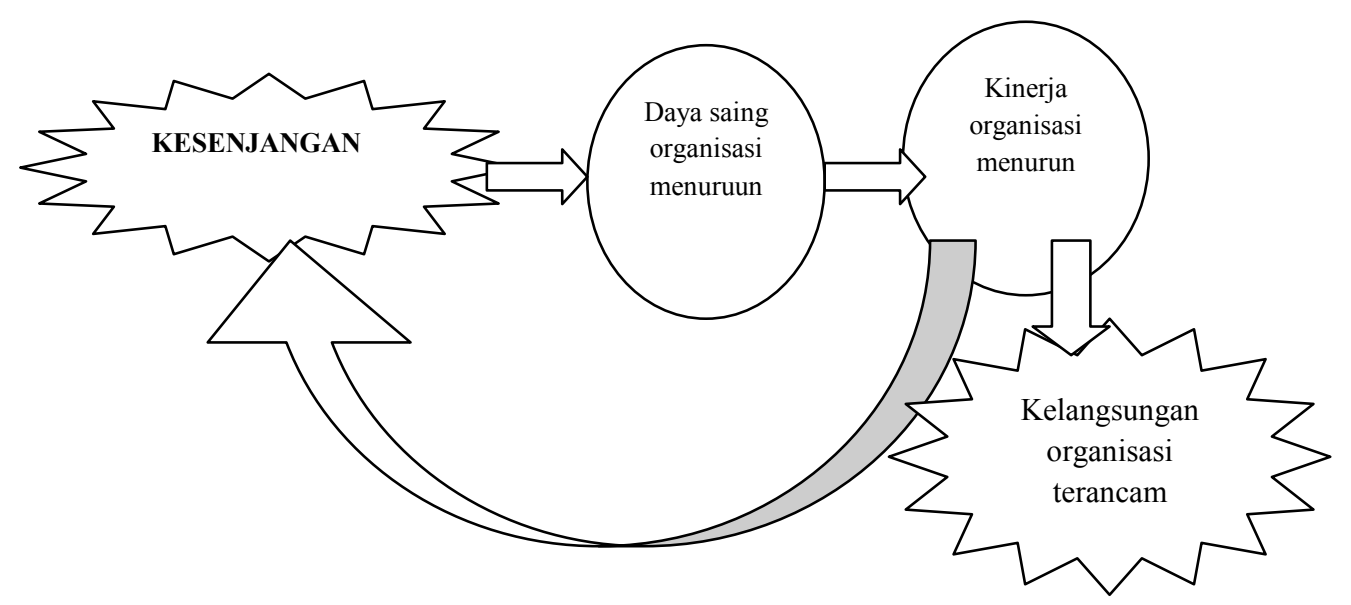

Gambar 1. Hubungan kesenjangan, daya saing, kinerja organisasi, dan kelangsungan organisasi. 
bahwa pandangan informasi adalah power, namun terbukti bahwa kepemilikan informasi saja tidaklah cukup, yang lebih utama adalah bagaimana informasi tersebut di putuskan dan menjadi pertimbangan sehingga menjadi ide, dan ide tersebut selanjutnya diberi konteks sehingga menjadi pengetahuan.

Knowledge dalam hal ini tidak diterjemahkan, karena pengertiannya masih diperdebatkan. Knowledge bukan hanya pengetahuan, menurut Thomas Davenport dan Laurence, knowledge didefinisikan sebagai berikut: "Knowledge merupakan campuran dari pengalaman, nilai, informasi kontektual, pandangan pakar dan intuisi mendasar yang memberikan suatu lingkungan dan kerangka untuk mengevaluasi dan menyatukan pengalaman baru dengan informasi. Di perusahaan knowledge sering terkait tidak saja pada dokumen atau tempat penyimpanan barang berharga, tetapi juga pada rutinitas, proses, praktek dan norma perusahaan.(Dave: 1998).

Ratna Indriyati dalam sebuah tulisan menjelaskan bahwa kajian tentang knowledge management (manajemenen pengetahuan) mulai mengemuka sejak tahun 1990 -an yang diprakarsai oleh para praktisi bisnis. Salah satu alasan yang mendorong mereka melakukan kajian itu adalah karena disadari bahwa aspek pengetahuan merupakan modalitas penting yang tidak bisa diabaikan dalam dunia bisnis. Kedudukan pengetahuan di era informasi ini setara dengan keberadaan energi pembangkit listrik di era industri. Di era informasi saat ini paradigma tentang modal mulai berkembang. Dahulu ruang lingkup modal berkisar pada modal finansial, infrastruktur, dan pada entitasentitas benda lainnya. Tetapi kini modal intelektual disadari merupakan modal sangat penting yang dapat mendongkrak nilai tambah suatu perusahaan.

Horwitc dan Armacost dalam bukunya Sangkala mendefinisikan manajemen pengetahuan adalah pelaksanaan penciptaan, penangkapan, pentransferan, dan pengaksesan pengetahuan dan informasi yang tepat ketika dibutuhkan untuk membuat keputusan yang lebih baik, bertindak dengan tepat, serta memberikan hasil dalam rangka mendukung strategi bisnis.

Pengetahuan Manajemen pengetahuan (knowledge management) ialah suatu rangkaian kegiatan yang digunakan oleh organisasi atau perusahaan untuk mengidentifikasi, menciptakan, menjelaskan, dan mendistribusikan pengetahuan untuk digunakan kembali, diketahui, dan dipelajari di dalam organisasi. Kegiatan ini biasanya terkait dengan objektif organisasi dan ditujukan untuk mencapai suatu hasil tertentu seperti pengetahuan bersama, peningkatan kinerja, keunggulan kompetitif, atau tingkat inovasi yang lebih tinggi.

Dari berbagai definisi di atas maka menurut penulis bahwa manajemen pengetahuan dapat digunakan untuk mengembangkan organisasi dalam lembaga pendidikan Islam guna menanggapi perubahan dan tuntutan kebutuhan zaman. Berdasarkan definisi tersebut, knowledge menjadi sangat penting dengan alasan sebagai berikut: Pertama, knowledge adalah aset institusi, yang menentukan jenis tenaga kerja, informasi, ketrampilan dan struktur organisasi yang diperlukan. Kedua, pengetahuan dan pengalaman perusahaan merupakan sumber daya yang berkelanjutan (sustainable resources) dari keuntungan daya saing kompetitif (competitive advantages) dibandingkan dengan produk andalan dan teknologi tercanggih yang dimiliki. Ketiga, pengetahuan dan pengalaman mampu menciptakan, mengkomunikasikan dan mengaplikasikan pengetahuan mengenai semua hal terkait untuk mencapai tujuan bisnis.

\section{Knowledge Management Landasan Pengembangan Organisasi Di Sekolah}

Sekolah pada hakikatnya adalah sistem yang hidup. Tanpa manusia, sekolah itu tidak berarti konkret dan ada. Sebagai sistem yang hidup, sekolah berada pada proses interaksi yang konstan bersama masyarakat, kelompok, tenaga kerja, universitas, gereja, dan lembaga lainnya. Sesungguhnya, sekejap tampak bahwa distrik sekolah yang besar sebagai suatu sistem yang menghindari kompleksitas. Organisasi pendidikan adalah tempat untuk 
melakukan aktivitas pendidikan untuk mencapai tujuan pendidikan yang diinginkan, dan pengorganisasian pendidikan adalah sebuah proses pembentukan tempat atau sistem dalam rangka melakukan kegiatan kependidikan untuk mencapai tujuan pendidikan yang diinginkan. Budaya organisasi mempunyai beberapa fungsi, diantaranya adalah (1) memberikan identitas organisasi kepada anggotanya (2) memudahkan komitmen kolektif(3) mempromosikan stabilitas sistem sosial, dan (4) membentuk perilaku dengan manajer merasakan keberadaanya. Dari pemaparan ini dari pemaparan di atas dapat disimpulkan bahwa knowledge management dapat digunakan untuk meningkatkan kinerja organisasi, dalam hal ini organisasi dalam lingkup lembaga pendidikan Islam.

Knowledge Management (KM) sebagai suatu konsep/teori dan praktek, tidak dapat dipungkiri lagi setelah menjadi isu sentral dan telah menjadi era baru dalam dunia manajemen, ekonomi global saat ini. Despres dan Chauval menjelaskan bahwa salah satu indicator melonjaknya perhatian terhadap Knowledge Management adalah meningkatnya artikel-artikel tentang KM sejak tahun 1988 - 1999, seperti digambarkan sebagai berikut:

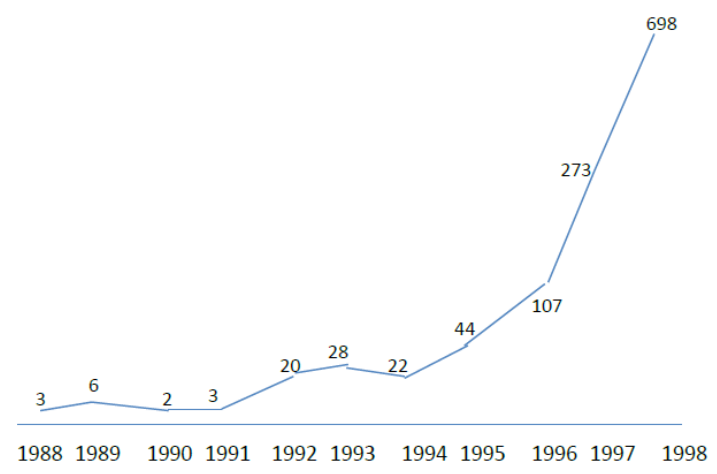

Gambar 2. Meningkatnya artikel yang berkaitan dengan Knowledge Management dari tahun ke tahun.

Tabel di atas menunjukkan bahwa perhatian terhadap Knowledge Management dalam era manajemen dan ekonomi global melonjak pesat sejak tahu 1995 ke atas. Mengacu pada hal ini, Despres dan Chauval mencoba menganalisis model-model konseptual
Knowledge Management yang diajukan oleh beberapa pakar. Tentu saja para pakar tersebut, mengkonstruksi konsep KM secara bervariasi menurut perspektif tacit dan (explicit knowledgenya) masing-masing berdasarkan serangkaian pengalaman dan penelitian yang panjang. Masing-masing ada yang mengkonstruksikan modelnya secara sederhana dan ada pula yang rinci dan kompleks.

Secara umum Knowledge Pengetahuan meliputi beberapa aspek, diantaranya : Pertama, apa, adalah acuan tentang obyek sentral yang dikelola dalam KM. Bicara obyek KM maka terdiri dari dua jenis, yaitu pengetahuan tacit (tacit knowledge) dan pengetahuan eksplisit (explicit knowledge). Walapun beberapa pakar menamakannya dengan istilah berbeda, seperti articulated knowledge (model N-Form Organization, Hedlund) untuk pengetahuan eksplisit atau knowing (model Knowling and Knowledge, Earl dan model OK Net, Carayannis) untuk pengetahuan (knowledge). Obyek sentral ini, pada akhirnya akan menjadi asset intelektual, modal intelektual dan menjadi human capital bagi organisasi (model Edvinsson, model Snowden, model Van Buren). kedua, siapa. adalah acuan tentang aktor pelaksana daripada KM tersebut dalam proses implementasinya. Aktor pelaksana tersebut adalah agregasi sosial yang meliputi individu (dalam dan luar organisasi, kelompok/komunitas (dalam dan luar organisasi), dan organisasi itu sendiri. Ketiga, bagaimana. adalah acuan tentang bagaimana proses obyek dan aktor pelaksana KM memperoleh dan mentrasnformasi pengetahuan. Nonaka menamakannya dengan dinamika interaksi (interaction dynamic). Dalam semua model membahas bagaimana proses aktifitas atau interaksi yang sebaiknya terjadi, tapi tidak semua secara eksplisit menjelaskan bagaimana peran teknologi dalam mendukung proses tersebut. Keempat, dimana. adalah acuan tentang ruang atau tempat tentang dinamika interaksi atau aktifitas perolehan dan penciptaan pengetahuan terjadi. Hampir semua model menjelaskan level ruang sosial tempat terjadinya aktifitas, yaitu level individu, kelompok, organisasi dan lintas organisasi. 
Seperti telah diketahui bahwa orangorang yang bekerja di dalam sebuah organisasi bukanlah suatu entitas yang homogen. Organisasi pada dasarnya terdiri dari orangorang yang memiliki latar belakang sosial, budaya, ekonomi, dan bahkan politik yang berbeda. Termasuk dalam organisasi pengelola pendidikan Islam, oleh karena itu, seringkali sebuah organisasi yang bermaksud melakukan perubahan supaya kinerjanya lebih baik ternyata gagal ditengah jalan. Apabila diteliti lebih jauh, ternyata penyebab kegagalan organisasi tersebut karena ketidakmampuan mengatasi atau berupaya meminimalkan perbedaan tersebut. Kondisi demikian kemungkinannya bisa juga terjadi ketika sebuah organisasi ingin menerapkan manajemen pengetahuan. Untuk melaksanakan dan menerapkan model ini tentu diperlukan langkah-langkah perubahan yang sistematis.

Permasalahan ini juga tidak melewatkan organisasi lembaga pendidikan Islam. Sehingga untuk mengembangkan aset pengetahuan tersebut pendidikan Islam dapat menggunakan pendekatan knowledge management. Agar perubahan yang dilakukan di tubuh lembaga pendidikan Islam berlangsung dengan sukses, maka formula strategi menjadi satu kebutuhan. Fungsi formulasi strategi dalam konteks ini lebih menitik beratkan pada upaya memberikan bahasa dan pemahaman serta sudut pandang yang sama.

Dalam pelaksanaannya, manajemen pengetahuan dapat dilihat dari beberapa dimensi, dari dimensi-dimensi inilah pendidikan Islam dapat menerapkan manajemen pengetahuan untuk mengembangkan pengorganisasian di lembaga pendidikan Islam. Diantara dimensi manajemen pengetahuan yang dapat dikembangkan lembaga pendidikan Islam menurut sangkala adalah, Pertama. konseptual. Agar organisasi (lembaga pendidikan Islam) mampu mengembangkan suatu konstruksi yang terintegrasi dan dapat digunakan untuk mendiskusikan pengetahuan di dalam organisasi. Alasannya adalah baik secara konsep maupun teori, manajemen pengetahuan memerlukan pendekatan yang menyeluruh. Berbagai konseptual yang dikeluarkan masing-masing anggota dalam lembaga pendidikan Islam harus dikemas oleh suatu teori yang sesuai dengan kebutuhan dengan jawaban dari berbagai pertanyaan organisasi yang terkait dengan penerapan manajeman pengetahuan.

Kedua, Perubahan. Dimensi ini penting mendapatkan perhatian karena perubahan terkait erat dengan stabilitas. Oleh karena itu, kerangka kerjanya terkait dengan institusi dan perkembangannya. Sebelum pengetahuan baru mengubah struktur pengetahuan dan sistem aktivitas di dalam organisasi, pengetahuan harus terlebih dahulu harus dapat diakses, dipahami, dan dapat diterima. Kerangka kerja manajemen pengetahuan ditunjukkan untuk mengubah organisasi sehingga dibutuhkan pula konsep mengenai manajemen perubahan. Hal ini memerlukan kerja sama dari aktivitas yang berbeda-beda antara yang satu dengan yang lain.

Ketiga, Pengukuran. Pengukuran menjadi aspek penting dalam organisasi (lembaga pendidikan Islam) karena merupakan mekanisme pengintegrasi di dalam organisasi. Masingmasing sistem pengukuran secara implisit menentukan sudut pandang. Oleh karena itu, desain pengukuran merupakan pernyataan yang paling fundamental dari sasaran organisasi. Pengukuran juga memungkinkan untuk dilihat apakah kita telah bergerak ke arah sasaran atau tidak.

Keempat, Struktur organisasi. Struktur organisasi juga menjadi hal yang penting diperhatikan yang di dalamnya terdapat pembagian peran dan tanggung jawab yang diperlukan agar efektivitas manajemen pengetahuan dapat terlaksana. Peran-peran tersebut diantaranya pemilik pengetahuan, penyebar pengetahuan, pencarian pengetahuan, dan koordinator komunitas.

Kelima, Isi pengetahuan. Apabila pengetahuan dipandang sebagai produk, pengetahuan dapat diklasifikasikan dan dikategori dalam berbagai cara. Untuk mengelola produk dari proses pengetahuan, kita memerlukan pengetahuan yang cocok dan saling mendukung. Isi pengetahuan juga terkait dengan keterampilan karyawan, dalam 
hal lembaga pendidikan Islam, tentunya dari tenaga pendidik dan tenaga kependidikan. Untuk mengelola isi pengetahuan dapat dikembangkan direktori keahlian, sistem pengelolaan ketrampilan, peta pengetahuan, atau model-model isi pengetahuan.

Keenam, Alat. Dimensi ini terkait erat dengan ketersediaan sarana untuk memperoleh pengetahuan. Oleh karena itu, bagaimana metodologi mengelola pengetahuan, representasi pengetahuan yang akan dikelola serta insfrastruktur yang dibutuhkan untuk menunjang pengelolaan pengetahuan secara efektif menjadi sesuatu yang turut menentukan strategi manajemen pengetahuan.

Tawaran lain tentang implementasi KM disampaikan Tiwana, dalam bukunya sangkala. Dia menawarkan bagaimana strategi menerapkan manajemen pengetahuan dalam organisasi yang dalam hal ini kita gunakan dalam lembaga pendidikan Islam. Setidaknya ada sepuluh langkah strategi yang dapat dilakukan untuk mengembangkan knowledge management, yaitu: Analisi infrastruktur yang ada. Tujuannya untuk menentukan teknologi apa yang saat ini telah dimiliki, dan teknologi apa yang seharusnya ditambahkan untuk meningkatkan dukungan manajemen pengetahuan di dalam lembaga pendidikan Islam. Langkah selanjutnya adalah mengaitkan manajemen pengetahuan dengan strategi bisnis. Bila penciptaan pengetahuan ingin sukses diarahkan, perlu disusun langkah yang mengaitkan antara strategi bisnis yang dibangun lembaga pendidikan Islam dengan strategi pengetahuannya. Langkah selanjutnya adalah mendesain infrastruktur manajemen pengetahuan. Tahap ini pihak manajemen sudah harus menentukan sejak awal jenis teknologi dan alat-alat apa saja yang dibutuhkan untuk sistem manajemen pengetahuan yang akan diterapkan.

Langkah selanjutnya adalah mengaudit aset dan sitem pengetahuan yang ada. Tujuan audit adalah untuk menilai apa saja pengetahuan yang sudah ada di dalam lembaga pendidikan Islam saat itu, dan menentukan fokus aktivitas manajemen pengetahuan. Setelah itu dilaksanakan untuk mendesain tim manajemen pengetahuan. Tim manajemen pengetahuan digunakan untuk fokus mendesain kebutuhan lembaga pendidikan Islam dan mengembangkannya. Setelah semua langkah tentang audit dilaksanakan selanjutnya adalah menciptakan blueprint manajemen pengetahuan dan pengembangan sistem manajemen pengetahuan Pada tahap ini tim harus bekerja keras sekaligus menggabungkan sistem manajemen pengetahuan yang sudah bangun tahap enam sebelumnya yang selanjutnya. Prototipe dan uji coba. Langkah ini merupakan upaya untuk menguji prototipe yang sudah dibuat sebelumnya, dan memperbaiki sistem yang tidak berjalan sesuai dengan rencana. Langkah

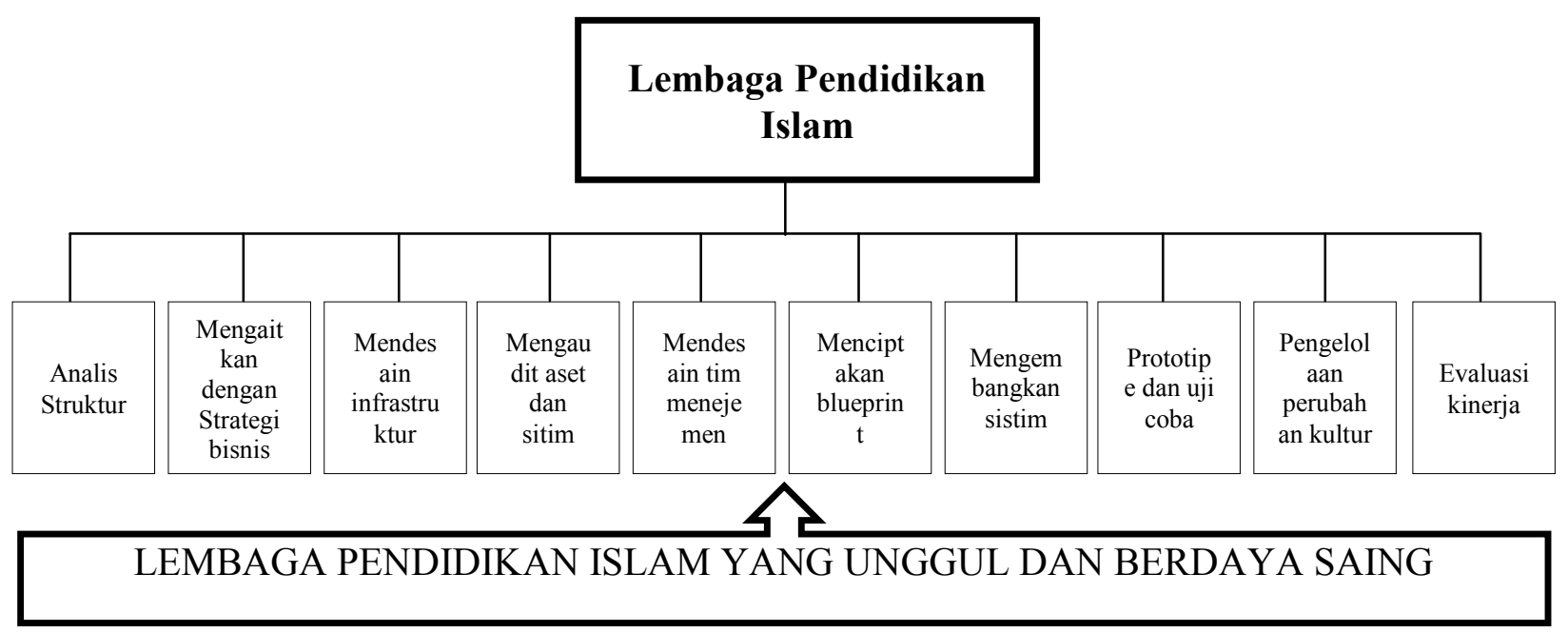

Gambar 3. Sistem Knowledge Management lembaga pendidikan Islam 
selanjutnya adalah pengelolaan perubahan, kultur, dan struktur penghargaan. Dalam tahap ini yang harus dicatat dalam kaitannya dengan upaya menjalankan tahap ini bahwa sukses dan tidaknya manajemen perubahan tidak hanya tergantung pada teknologi, akan tetapi juga dipengaruhi kultur dan sistem penghargaan.

Langkah terakhir adalah evaluasi kinerja, mengkur, dan perbaikan sistem manajemen pengetahuan. Penutup langkah ini adalah dengan rencana implementasi dengan menanamkan dengan pengukuran hasil manajemen pengetahuan sambil secara simultan mengakui sejak awal masalah utama dari realitas pengukuran. Untuk memperjelas sistem knowledge management pada lembaga pendidikan Islam dapat dilihat pada struktur gambar 3 .

\section{KESIMPULAN}

Berdasarkan hasil pembahasan yang dikemukakan pada pembahasan di atas tentang knowledge Management, dapat kita simpulkan bahwa Knowledge Management adalah suatu rangkaian kegiatan yang digunakan oleh organisasi atau perusahaan untuk mengidentifikasi, menciptakan, menjelaskan, dan mendistribusikan pengetahuan untuk digunakan kembali, diketahui, dan dipelajari di dalam organisasi. Kegiatan ini biasanya terkait dengan objektif organisasi dan ditujukan untuk mencapai suatu hasil tertentu seperti pengetahuan bersama, peningkatan kinerja, keunggulan kompetitif, atau tingkat inovasi yang lebih tinggi. Knowlegde Management (Manajeman Pengetahuan) sebagai pendekatan yang bertumpu pada pemahaman bahwa tugas sekolah adalah memahami dengan baik bagaimana dan kapan penciptaan pengetahuan harus didukung, bagaimana menggunakan akumulasi pengetahuan yang sudah tercipta sehingga pengetahuan tersebut dapat meningkatkan produktifitas.

Dengan mengumpulkan pengetahuan yang ada pada lembaga pendidikan Islam, kemudian di formulasikan dan desain dengan baik, akan menjadikan lembaga pendidikan Islam yang unggul dan berdaya saing. Menejemen ini tidak terlalu rumit untuk dilakukan. Dengan modal pengetahuan dan kemampuan pimpinan untuk meramu aset pengetahuan dalam suatu lembaga pendidikan Islam akan membantu dan menjadikan lembaga pendidikan Islam yang semakin banyak ini dapat terus unggul dan berdaya saing.

Penerapan manajemen pengetahuan bukanlah pekerjaan yang sekali jadi dan dapat segera dilihat hasilnya, tetapi lebih kepada proses kerja keras yang panjang mengingat hal ini adalah pendekatan yang unik dan sangat terkait dengan karakteristik masing-masing organisasi lembaga pendidikan Islam. Apabila menejemen lembaga pendidikan Islam berjalan baik, maka seluruh aspek yang berkaitan dengan lembaga akan berjalan baik dan tujuan yang ingin dicapai dapat terwujud.

\section{DAFTAR PUSTAKA}

Abudin Nata, Manajeman Pendidikan, Mengatasi Kelemahan Pendidikan Islam di Indonesia. Jakarta: Prenada Media Group, 2008, cet. 3.

Ara Hidayat dan Imam Machali, Pengelolaan Pendidikan, Konsep, Prinsip, dan Aplikasi dalam emngelola sekolah dan madrasah, Yogyakarta: Kaukaba, 2012.

Despres, Charles and Chauval, Daniele, "Knowledge Horizons: The Present and The Promise of Knowledge Management", Boston, Oxford, Auckland, Johannesberg, Melbourne, New Delhi: Butterworth Heinemann, 2000.

Hendro Setiadi, makalah Penerapan Knowledge Management Pada Perusahaan Reasuransi, Fakultas Ilmu Pendidikan Universitas Pendidikan Indonesia tahun 2011.

Hendyat Soetopo, Perilaku Organisasi, Teori dan Praktik dalam bidang Pendidikan, Bandung: Remaja Rosdakarya, 2010.

Husaini Usman, Manajemen Teori, Praktik, dan Riset Pendidikan, Jakarta: Bumi Aksara, 2006.

Jalaluddin Rahmat, Islam Menyongsong Peradaban Dunia Ketiga, dalam Ulumul Quran, Vol.2, 1989. 
Jusuf Amir Faisal, Reorientasi Pendidikan Islam, Jakarta: Gema Insani Pers, 1995, cet. 1 .

M. Fakry, dkk ed, Manajemen Corporate dan Strategi Pemasaran Jasa Pendidikan, Bandung: Alfabeta, 2008.

Marno dan Triyo Supriyatno, Manajemen dan Kepemimpinan Pendidikan Islam. Bandung: Refika Aditama, 2008.

Mujami Qomar, Manajemen Pendidikan Islam, Strategi Baru Pengelolaan Lembaga Pendidikan Islam.Jakarta: Erlangga, 2007.
Nazarudin, Manajemen Pembelajaran, Implementasi Konsep, Karakteristik dan Metodedologi Pendidikan Agama Islam di Sekolah Umum, Yogyakarta: Teras, 2007.

Praktisi Manajemen Keuangan; Bekerja sebagai Pengelola Keuangan di IAIN Sunan Ampel Surabaya.

Sangkala, Knowledge Management, Jakarta: Raja Grafindo Persada, 2007.

Undang-Undang No. 20 Tahun 2003 tentang sistem pendidikan nasional pasal 1 . 